\title{
Detection of Trace Elements in Selective Dairy Products to assess Human Health Risk of Bangladeshi People
}

\author{
G. M. M. ANWARUL HASAN ${ }^{1 *}$ and SANJIDA KHANAM ${ }^{2}$ \\ ${ }^{1}$ Institute of Food Science and Technology (IFST), Bangladesh Council of Scientific and Industrial \\ Research (BCSIR), Bangladesh. \\ ${ }^{2}$ Department of Biochemistry and Molecular Biology, Jahangirnagar University, Bangladesh. \\ ${ }^{*}$ Corresponding author E-mail: ifstbcsir@yahoo.com \\ http://dx.doi.org/10.13005/ojc/370222
}

(Received: January 01, 2021; Accepted: March 02, 2021)

\begin{abstract}
Heavy metal mediated toxicity is associated with several health risks. In this research, heavy metal contents in selected dairy products such as Cheese, Ghee (Local processed dairy product) and Butter were determined and studied their effects on human health. From the results, it was determined that, $\mathrm{Cu}$ had the highest concentration and daily intake rate in Cheese, Ghee and Butter samples; while $\mathrm{Pb}$ had the lowest concentration and daily intake rate in Cheese and Butter samples. The estimated daily intake (EDI) values of all these metals were less than the permissible value. Also the results of THQ (Target hazard quotient), TTHQ (Total target hazard quotient) and TCR (Target Carcinogenic risk) suggested that, all of these values of these dairy product samples were less than the risk value. Our current study indicated that there is no chance of any kind of health risk through the consumption of these dairy products.
\end{abstract}

Keywords: Heavy metals, Cheese, Ghee, Butter, Bangladesh, Health risk.

\section{INTRODUCTION}

Milk and milk products are considered to be highly important foods because they contain large quantities of nutritional constituents such as proteins, minerals and vitamins ${ }^{1}$. In our daily diet, milk and milk products are important components especially for mothers, school-age children and the elder people ${ }^{2}$.

In terms of composition, there are twenty different trace elements found in milk and milk products which are known as the most diversified natural foodstuffs. Most of them, including copper, zinc, manganese and iron are basic and very necessary ${ }^{3-5}$. In certain enzymes, these metals acts as co-factors and play an important part in many human and animal physiological functions. Lack of these metals can cause disorders and pathological disorders ${ }^{6,7}$.

Milk and milk products can be contaminated by several sources such as heavy metals, mycotoxins and residues of veterinary drugs. Heavy metals are one of the most significant and most complicated pollutants ${ }^{8-11}$. Contamination occurs primarily

This is an Open Access article licensed under a Creative Commons license: Attribution 4.0 International (CC- BY). Published by Oriental Scientific Publishing Company @ 2018

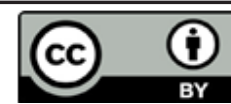


because of the ingestion of contaminants by animals consuming milk or because of contamination during milk production ${ }^{12}$. This could lead to heavy metal bioaccumulation and probably a high risk of human exposure to these pollutants in their meat and the milk provided. It is generally recognized that, certain elements are important for the human body, in trace concentrations. However, their intake at levels higher than the recommended concentrations can have adverse consequences ${ }^{13}$. Thus, exposure to heavy metals in food poses a danger to human health ${ }^{14}$.

The proper quantity of metals in good milk is beneficial, but the quality of milk can be considerably altered by the manufacturing and packaging process. Milk quality can also be altered by metals such as lead, cadmium, chromium, nickel and cobalt through contaminating cattle feed and environment. Later, those metals could be excreted into milk at different levels ${ }^{15,16}$ and cause serious problems.

Heavy metals cause severe health issues, so the correct assessment of their residues is severely impaired. The side effects of these metals include nervous system disorders, renal failure, genetic mutations, cancer types, neurological disorders, respiratory and cardiovascular disorders, weakness and infertility of the immune system ${ }^{17}$. Lead also causes serious diseases of our body including damage to central nervous system, anemia, damage to the kidneys, the liver, the heart and blood vessels, the immune system, the digestive tract, the genital system and various cancers ${ }^{18,19,20}$. Encephalitis and hepatitis ${ }^{20}$ can also be caused by lead. In tissues such as the liver and the kidneys, cadmium accumulates, causing anemia and a rise in blood pressure ${ }^{21}$. Cadmium is extremely carcinogenic to the lungs and prostate and is responsible for the growth of the tumor. Cadmium induces inflammation of the kidneys, bones, lungs, liver, heart and vessels ${ }^{20}$. Nickel also occurs serious problems in our body including a number of blood, brain and bone cancers and local infections are caused by nickel20. Also include disruption of cell biological activity, delayed development, decreased hematuria, and iron absorption interference are occur due to nickel poisoning 22 . Nickel salt cause respiratory problems and affect the heart after entering the bloodstream.

There are several factors associated with the quantity of toxicity such as route, quantity of use, solubility, status of metal oxidation, percentage of maintenance, length of use, age, gender and frequency of use, rate of absorption and efficacy of excrement mechanisms ${ }^{23}$.

Cheese is a dairy product derived from milk by coagulation of the milk protein casein. Cheese comprises proteins and fat from milk. Ghee is a local dairy product obtained from milk, cream or butter of different species of animals through processes that result in the almost total removal of moisture and solids-not-fat and give a specific physical structure to the product. The standard ghee contains $96 \%$ minimum milk-fat, $0.3 \%$ maximum moisture, $0.3 \%$ maximum free fatty acids (FFA) and a peroxide value less than $1.0^{24}$. Butter is produced worldwide from a range of animal milk, including cow, goat, camel, buffalo and sheep ${ }^{25}$. Butter is called yellow fat which is used for spreading on bread or for indirect consumption as ingredients in other foods ${ }^{26}$.

The purpose of this research was to determine the contents of selected heavy metals (Fe, $\mathrm{Cu}, \mathrm{Cr}, \mathrm{Cd}, \mathrm{Ni}, \mathrm{Mn}, \mathrm{Pb}, \mathrm{Zn}, \mathrm{As}$ ) in Cheese, Ghee and Butter samples from different areas of Bangladesh and to observe the possible carcinogenic and non-carcinogenic health risks of Bangladeshi adult peoples from the consumption of these products. This study was conducted to concern the Bangladeshi people to properly know the harmful effects of heavy metals through consumption of milk products.

\section{MATERIALS AND METHODS}

\section{Study area}

In this study, three types of dairy products including Cheese, Ghee and Butter samples were collected from different districts of Bangladesh.

\section{Sample Collection and Preparation}

For this study, 128 Cheese, 128 Ghee and 128 Butter samples were purchased from the local shops of different districts of Bangladesh. We used standard methods to keep all the samples in sterile glass bottles. After keeping the samples in sterile glass bottles, instantly the glass bottles were kept in freeze to maintain the temperature as needed for these dairy samples. The samples were carried to the laboratory as soon as possible and stored at $4^{\circ} \mathrm{C}$ until analysis. The analysis process was started within $24 \mathrm{~h}$ after storing the samples. It was noticed that the samples carrying glass bottles were not in touch of any metal sources. In this research, the 
amount of selected heavy metals including Iron $(\mathrm{Fe})$, Manganese $(\mathrm{Mn})$, Zinc $(\mathrm{Zn})$, Copper $(\mathrm{Cu})$, Chromium ( $\mathrm{Cr}$ ), Cadmium ( $\mathrm{Cd})$, Lead $(\mathrm{Pb})$ and Arsenic (As) were determined from selected dairy samples. The research work was conducted at Milk, Dairy and Fermented Food Products Research Section of Institute of Food Science and Technology of Bangladesh Council of Scientific and Industrial Research (BCSIR), Bangladesh from October 2018 to July 2019.

\section{Sample Digestion}

In this study, we extracted elements from the samples using a microwave digestion system (Model: Speed wave, Berghof, Germany). We used an optimized 3 steps program for dairy products with maximum temperature $200^{\circ} \mathrm{C}$, maximum pressure 35 bar and maximum $90 \%$ power. For digestion, we used $5 \mathrm{~mL} \mathrm{HNO}_{3}$ acid (65\% pure, Merck, Germany) and 2 $\mathrm{mL} \mathrm{H}_{2} \mathrm{O}_{2}$ (30\% pure, Merck, Germany). $0.3 \mathrm{~g}$ samples were then taken with the digestion reagent in a Teflon vessel. We moved the samples into a beaker when the digestion was finished. To produce a total volume of up to $25 \mathrm{~mL}$, we used Milli-Q water (Millipore, USA). Finally, we filtered the solution (PTFE, $0.45 \mu \mathrm{m}$ ) with a syringe filter. The whole solution was stored in a plastic tube with a screw cap.

\section{Sample Analysis}

In this research, heavy metals were analyzed through Atomic Absorption Spectrophotometer (iCE -3000 series, Thermo-Scientific, USA). The standard solution for this technique was purchased from Sigma-Aldrich, USA. For $\mathrm{Cd}, \mathrm{Cr}, \mathrm{Cu}, \mathrm{Mn}, \mathrm{Pb}$, $\mathrm{Fe}, \mathrm{Zn}$ and As, the used spectral lines were 228.67, $357.65,324.57,279.43,217.35,213.9,248.30$ and $193.7 \mathrm{~nm}$ respectively. At $0.01,0.1,1.0,5.0$ ppm (parts per million), we prepared four standard solutions of each metal. The minimum detection limit was $0.005 \mathrm{mg} / \mathrm{kg}$ for $\mathrm{Cr}$ and $\mathrm{Zn}, 0.002 \mathrm{mg} / \mathrm{kg}$ for $\mathrm{Mn}$ and $\mathrm{Pb}$, and $0.001 \mathrm{mg} / \mathrm{kg}$ for $\mathrm{Cd}$, Fe and Cu. Certified reference materials (CRMs) (Sigma Aldrich, USA) are used to verify the accuracy of the samples.

\section{Health risk assessment procedure Estimated Daily Intake (EDI) of heavy metals} the following equation:

The EDI of these metals was calculated by

$$
\mathrm{EDI}=\frac{D i \times M c}{B W}
$$

Where, $\mathrm{Di}$ is the daily consumption rate of
Cheese, Ghee and Butter (mg/day) for Bangladeshi adult peoples; the Di values are14.053, 786.965 and $14.053 \mathrm{mg} /$ day for Cheese, Ghee and Butter respectively ${ }^{27}, M C$ is the metal concentration in Cheese, Ghee and Butter samples which is presented in the Table $1(\mathrm{mg} / \mathrm{kg}$ on fresh weight basis), and BW indicates the average body weight of the adult population which is $60 \mathrm{~kg}^{28}$.

\section{Target Hazard Quotient (THQ)}

The target hazard quotient (THQ) is calculated to estimate potential risk of these heavy metals ${ }^{29}$. The equation is:

$$
\mathrm{THQ}=\frac{E D I}{R f D} \times 10^{-3}
$$

Here, EDI represents the estimated daily intake of metals (mg/day), RfDs indicates reference dose; the reference doses for $\mathrm{Fe}, \mathrm{Cu}, \mathrm{Mn}, \mathrm{Zn}, \mathrm{Pb}$, $\mathrm{Cd}, \mathrm{Cr}$ and As are 0.7, 0.04, 0.05, 0.3, 0.004, 0.001, 1.5 and $0.0003 \mathrm{mg} / \mathrm{kg} / \mathrm{BW} / \mathrm{day}^{30}$. When the value of THQs is equal or higher than 1 , it indicates the potential health risk ${ }^{31}$.

When consumers are exposed to two or more pollutants, they may suffer from adverse or interactive effects ${ }^{32}$. The total THQ (TTHQ) values can be estimated by the following equation:

$\mathrm{TTHQ}=\mathrm{THQ} \mathrm{t}_{\text {toxic element1 }}+\mathrm{THQ}_{\text {toxic element 2 }}+\ldots+\mathrm{THQ}$ toxic element $n$

\section{Target Carcinogenic risk (TCR)}

When the carcinogens are to be exposed over lifetime, the probability of cancer of an individual can be developed ${ }^{33}$. For carcinogens, the acceptable risk level ranges from $10^{-4}$ to $10^{-6}$. The equation is:

$$
\mathrm{TCR}=\frac{E F r \times E D \times E D I \times C S F^{\circ}}{B W \times A T} \times 10^{-3}
$$

Where, EFr means frequency of exposure (365 days/year), ED is the duration of exposure and it is 70 years for adult people, BW is the average body weight which is $60 \mathrm{~kg}$, AT is the averaging time for carcinogens (365 days/year $\times 70$ years) for adults and $\mathrm{CSF}^{\circ}$ means the oral carcinogenic slope factor from the system of Integrated Risk Information ${ }^{30}$ database which is $1.5 \mathrm{mg} \mathrm{kg}^{-1}$ day $^{-1}$ and $0.0085 \mathrm{mg}$ $\mathrm{kg}^{-1}$ day $^{-1}$ for Arsenic and lead respectively and the oral carcinogenic slope factor of cadmium is $15 \mathrm{mg}$ $\mathrm{kg}^{-1}$ day $^{-135}$. 


\section{Statistical analysis}

In this analysis, we used one-way ANOVA test to measure the basic statistical characteristics, relevant differences and to analyze the experimental data. To analyze the experimental results, we used computer software such as Microsoft Office Excel 2016 and XL-stat version 17. Pearson's correlation coefficients in Cheese, Ghee and Butter samples were used to analyze the concentration of heavy metals.

\section{RESULTS AND DISCUSSION}

In this research, we estimated the amount of selected heavy metals in Cheese, Ghee and Butter samples. The determined heavy metals are Iron, Manganese, Zinc, Copper, Chromium, Cadmium, Lead and Arsenic. The metal concentrations of Cheese, Ghee and Butter samples are presented in Table 1. The descending order of Cheese, Ghee and Butter were $\mathrm{Cu}>\mathrm{Fe}>\mathrm{Cr}>\mathrm{Zn}>\mathrm{Mn}>\mathrm{Cd}$, $\mathrm{As}>\mathrm{Pb}$; Cu>Fe>Zn>Cr$>\mathrm{Mn}>\mathrm{Cd}>\mathrm{Pb}>\mathrm{As}$ and $\mathrm{Cu}>\mathrm{Cr}>\mathrm{Fe}>\mathrm{Zn}>\mathrm{Mn}>\mathrm{As}, \mathrm{Cd}>\mathrm{Pb}$ respectively according to the mean value.

In each Cheese, Ghee and Butter samples, $\mathrm{Cu}$ had shown the highest concentration. Except Ghee, $\mathrm{Pb}$ had shown the lowest concentration. Among these Cheese, Ghee and Butter samples, the highest $\mathrm{Cu}$ concentration was found in the Butter sample which is $1.543 \mathrm{ppm}$.

\section{Health risk assessment}

By this analysis, we estimated the daily intake of selected eight heavy metals for potential health risks due to these dairy products. The values of EDIs of Cheese, Ghee and Butter were shown in the Table 2. The estimated daily intake (EDI) is the ratio of the mean metal concentrations, the daily consumption rate of dairy products and the consumer's body weight ${ }^{28}$.

In this research, the daily intake of $\mathrm{Cu}$ had shown to have the highest value in Cheese, Ghee and Butter and the daily intake of $\mathrm{Pb}$ had shown to have the lowest value (mg/day) in Cheese and Butter. Among these three type dairy products, the highest daily intake of Cu was found in Ghee which is $14.3068 \mathrm{mg} /$ day and the lowest daily intake of $\mathrm{Pb}$ was found in Butter which is $0.00232 \mathrm{mg} /$ day. The permissible value of these selected heavy metals is shown in the Table 7. From the results of EDI, it can be seen that the daily intake of all

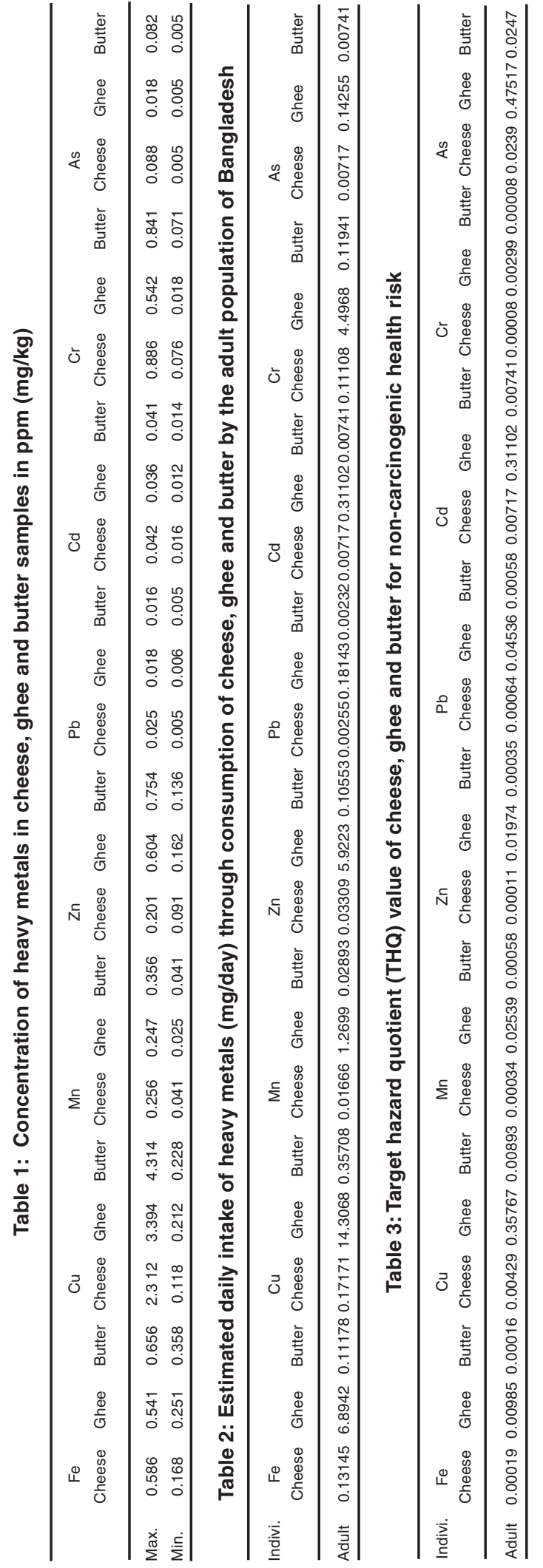


the heavy metals are below their permissible limit. On the basis of these results, it could be said that there is no chance of potential health risks through consuming these dairy products.

\section{Non- carcinogenic health risk}

We know, the target hazard quotient (THQ) is the ratio of the pollutant's determined dose to the level of the reference dose. From the concept of risk assessment, it is the method that assesses the possible health effects of one contaminant obtained through one or more mechanisms of exposure from doses to humans.

In this analysis, the estimated THQs of Cheese, Ghee and Butter samples are presented in Table 3.

From Table 3, it can be determined that, the estimated THQ value of all the metals from the intake of Cheese, Ghee and Butter samples is below the threshold value of 1 . Hence, it can be said that, there is no chance of non-carcinogenic health risks due to these metals. The THQ values are reduced in the order of $\mathrm{As}>\mathrm{Cd}>\mathrm{Cu}>\mathrm{Pb}>\mathrm{Mn}>\mathrm{Fe}>\mathrm{Zn}>\mathrm{Cr}$ among these Cheese, Ghee and Butter samples.

In this study, the TTHQ value of Cheese, Ghee and Butter samples is 0.03672, 1.24719 and 0.04279 respectively and presented in Table 4 . In fact, a TTHQ $<1$ does not indicate acute health effects of consumers ${ }^{32}$. The TTHQ value of Cheese and Butter samples was less than 1. But the TTHQ value of Ghee was greater than 1. So, it can be concluded that, there is no risk of adverse health effects through the consumption of Cheese and Butter. On the other hand, the Ghee consumption could be affected our health.

Table 4: Total target hazard quotient (TTHQ) value of cheese, ghee and butter samples for non-carcinogenic health risk

\begin{tabular}{llll}
\hline Individuals & Cheese & Ghee & Butter \\
\hline Adult & 0.03672 & 1.24719 & 0.04279 \\
\hline
\end{tabular}

\section{Carcinogenic health risk}

In this study, the TTHQ value of Cheese, Ghee and Butter samples is 0.03672, 1.24719 and 0.04279 respectively and presented in Table 4 . In fact, a $T T H Q<1$ does not indicate acute health effects of consumers ${ }^{36}$. The TTHQ value of Cheese and Butter samples was less than 1. But the TTHQ value of Ghee was greater than 1. So, it could be concluded that there is no risk of adverse health effects through the consumption of Cheese and Butter. On the other hand, the Ghee consumption could be affected our health.

The TCR values of $\mathrm{As}, \mathrm{Pb}$ and $\mathrm{Cd}$ of these samples are shown in Table 5.

Table 5: Target carcinogenic risks (TCR) of heavy metals ( $\mathrm{Pb}$, As and $\mathrm{Cd}$ ) due to consumption of cheese, ghee and butter in the population of different administrative areas of Bangladesh

\begin{tabular}{cccc}
\hline $\begin{array}{c}\text { Carcinogenic } \\
\text { metal }\end{array}$ & Cheese & Ghee & Butter \\
\hline As & $1.793 \mathrm{E}-7$ & $3.564 \mathrm{E}-6$ & $1.85 \mathrm{E}-7$ \\
$\mathrm{~Pb}$ & $3.613 \mathrm{E}-10$ & $2.57 \mathrm{E}-8$ & $3.29 \mathrm{E}-10$ \\
\hline
\end{tabular}

From Table 5, the highest $\mathrm{As}, \mathrm{Pb}$ and $\mathrm{Cd}$ value was found in Ghee. The value of As in Cheese, Ghee and Butter was 1.793E-7, 3.564E-6 and 1.85E-7 respectively. The value of $\mathrm{Pb}$ exposure Cheese, Ghee and Butter was 3.613E-10, 2.57E-8 and $3.29 \mathrm{E}-10$ respectively. The value of $\mathrm{Cd}$ in Cheese, Ghee and Butter was 1.793E-6, 7.776E-5 and $1.853 \mathrm{E}-6$ respectively. When the value remains below $10^{-6}$, the risk of cancer is generally considered minimal and when the value remains above $10^{-4}$ the risk of cancer is considered undesirable, and when the value gets between $10^{-6}$ and $10^{-4}$, it is generally considered an acceptable range ${ }^{30,33}$. From the results, we found that, the carcinogenic risk for both $\mathrm{As}, \mathrm{Pb}$ and $\mathrm{Cd}$ were below the minimal range in all the Cheese, Ghee and Butter samples. So, this study indicates that there are no carcinogenic health risks of Bangladeshi dairy products consumer through the consumption of Cheese, Ghee and Butter.

\section{CONCLUSION}

In this study, the concentration of selected heavy metals of Cheese, Ghee and Butter samples from 64 administrative districts of Bangladesh was calculated for health risk assessment. Cu showed the highest concentrations and $\mathrm{Pb}$ showed the lowest concentration among these eight metals along with their daily intake rate in all the samples. From the values of THQ and TTHQ, it can be seen that there is no potential non-carcinogenic health 
risks and adverse effects through the consumption of Cheese and Butter. But the consumption Ghee might have some adverse effects on our health. From the analyzed TCR values it was found that there is also no chance of carcinogenic health risks. The government of Bangladesh should be strict to their rules and regulations to ensure the proper quality dairy products to ensure more safety and consciousness during dairy products manufacturing. It is necessary to ensure the quality of milk, because the good quality milk products come from good quality milk. Hygiene must be maintained during the manufacturing process.

\section{ACKNOWLEDGEMENT}

The study was part of R\& D work of "Milk, Dairy and Fermented Product Research Section" of Institute of Food Science and Technology (IFST), BCSIR. All the instrument used in this study was supported by ADP project allocated by Ministry of Science of Technology, Bangladesh.

\section{Conflicts of Interest}

The authors declare no conflict of interest

\section{REFERENCES}

1. Shahbazi, Y.; Ahmadi, F. and Fakhari, F. Voltammetric determination of $\mathrm{Pb}, \mathrm{Cd}, \mathrm{Zn}, \mathrm{Cu}$ and $\mathrm{Se}$ in milk and dairy products collected from Iran: An emphasis on permissible limits and risk assessment of exposure to heavy metals. Food chemistry., 2016, 192, 10601067.

2. Enb, A.; Abou Donia, M.A.; Abd-Rabou, N.S.; Abou-Arab, A.A.K. and El-Senaity, M.H. Chemical composition of raw milk and heavy metals behavior during processing of milk products. Global Veterinaria., 2009, 3(3), 268-275.

3. Schroeder, H.A.The trace elements and nutrition. London: Faber and Faber., 1973.

4. WHO, World Health Organization. Trace elements in human. Who Technical Report Series, No. 532, 1973, WHO, Geneva.

5. Somers, E. The toxic potential of trace metals in foods. A review. Journal of Food Science., 1974, 39(2), 215-217.

6. Koh, T.S. and Judson, G.J. Trace-elements in sheep grazing near a lead-zinc smelting complex at Port Pirie, South Australia. Bull. Environ. Contam. Toxicol.; (United States), 1986, 37(1).

7. Schuhmacher, M.; Bosque, M.A.; Domingo, J.L. and Corbella, J. Dietary intake of lead and cadmium from foods in Tarragons Province, Spain. Bulletin of environmental contamination and toxicology., 1991, 46(2), 320-328.

8. Rokni N. Principles of food hygiene. Tehran., 2007, 4350.

9. Mahmoudi, R. and Zare, P. Total and M1 aflatoxins contamination in meat and milk buffalo were slaughtered in the Northwest of
Iran., 2014.

10. Fallah, S.S.; Fahimdanesh M. Reza M. Investigation of effect of grilland soak in citric acid and then grillon the changes of fe, pb and cd in sheep's liver. International Journal of Biology, Pharmacy and Allied Science, 2015, 4(5), 39-47.

11. Mahmoudi, R. and Emami, S.J. Honey contamination with heavy metals in Iran. Journal of Inflammatory Disease., 2015, 18(6), 67-70.

12. Pavlovic, l.; Sikiric, M.; Havranek, L.; Plavljanic, N. and Brajenovic, N. Lead and cadmium levels in raw cows milk from an industrialised Croatian region determined by electrothermal atomic absorption spectrometry. Czech Journal of Animal Science-UZPI (Czech Republic)., 2004.

13. Licata, P., Di Bella, G., Potortì, A.G., Lo Turco, V. and Salvo, A. Determination of trace elements in goat and ovine milk from Calabria (Italy) by ICP-AES Part B Surveillance., 2012.

14. Saei-Dehkordi, S.S. and Fallah, A.A. Determination of copper, lead, cadmium and zinc content in commercially valuable fish species from the Persian Gulf using derivative potentiometric stripping analysis. Microchemical Journal., 2011, 98(1), 156162.

15. Abou-Arab, A.A.K., Effect of Ras cheese manufacturing on the stability of DDT and its metabolites. Food Chemistry., 1997, 59(1), 115-119. 
16. Abou-Arab, A.A.K.; Kholif, A.M. and Abo El-Nor, S.A.H. Effect of spraying diazinon to control the external parasites on the productive performance of dairy animals. 3-Minerals contents of blood serum and milks. Egyptian Journal of Dairy Science., 1994, 22, 287-287.

17. Aazami, J., Moradpour, H. and KianiMehr, N. A Review of Biotic Indices for Heavy Metals in Polluted Environment. Human \& Environment., 2017, 15(1), 13-24.

18. Tavakoli-Hosseinabady, B.; Ziarati, P.; Ballali, $\mathrm{E}$. and Umachandran, K. Detoxification of heavy metals from leafy edible vegetables by agricultural waste: apricot pit shell. J Environ Anal Toxicol., 2018, 8(1), 548.

19. Alimardan, M.;Ziarati, P. and Jafari Moghadam, R. Adsorption of heavy metal ions from contaminated soil by B. integerrima barberry. Biomedical \& Pharmacology Journal., 2016, 9(1), 169-75.

20. Ziarati, P.; Moslehishad, M. and MohammadMakki, F.M. Novel adsorption method for contaminated water by wild endemic almond: Amygdalus scoparia. Biosciences biotechnology research asia., 2016, 13(1), 147-153.

21. Bonyadian, M.; Moshtaghi, H. and Sultani, Z. Study on the residual of lead and cadmium in raw and pasteurized milks in Shahrekord area., 2006.

22. Hamidi, R. and Daneshpajooh, M. Measuring the lead, arsenic, copper, zinc, selenium, sodium, potassium, nickel, and magnesium ions in black tea. Feyz, J Kashan Univ Med Sci., 2009, 13(13), 242-248.

23. Bilandžic, N., Sedak, M., Đokic, M., Božic, Đ., Solomun Kolanovic, B. and Varenina, I. Trace elements content in cheese, cream and butter. Mljekarstvo: casopis za unaprjedenje proizvodnje i prerade mlijeka., 2014, 64(3), 150-158.

24. Sserunjogi, M.L.; Abrahamsen, R.K. and Narvhus, J. A review paper: current knowledge of ghee and related products. International Dairy Journal., 1998, 8(8), 677-688.

25. Curry, A. Archaeology: the milk revolution. Nature News., 2013, 500(7460), 20.
26. Embaye, K. Analysis of butter supply chain. An MSc Thesis submitted to Haramaya University, Graduate Studies., 2010.

27. Bangladesh Bureau of Statistics. Report of the Household Income and Expenditure Survey (HIES)., 2011.

28. Shaheen, N.; Ahmed, M.K.; Islam, M.S.; Habibullah-Al-Mamun, M.; Tukun, A.B.; Islam, S. and Rahim, A.T.M. Health risk assessment of trace elements via dietary intake of 'nonpiscine protein source'foodstuffs (meat, milk and egg) in Bangladesh. Environmental science and pollution research., 2016, 23(8), 7794-7806.

29. USEPA. Risk-based concentration table. Washington, DC: United States Environmental Protection Agency., 2000.

30. USEPA. Risk Based Concentration Table., 2010.

31. Islam, M.S., Ahmed, M.K., Habibullah-AIMamun, M. and Masunaga, S. Trace metals in soil and vegetables and associated health risk assessment. Environmental monitoring and assessment., 2014, 186(12), 8727-8739.

32. Hallenbeck, W.H.Quantitative RiskAssessment for Environmental and Occupational Health, Lewis, Chelsea., 1993.

33. EPA, A. Risk assessment guidance for superfund. Volume I: human health evaluation manual (part a). 1989,EPA/540/1-89/002.

34. Muhib, M.I., Chowdhury, M. A. Z., Easha, N. J., Rahman, M.M., Shammi, M., Fardous, Z., \& Alam, M. K. (2016). "Investigation of heavy metal contents in Cow milk samples from area of Dhaka, Bangladesh". International journal of food contamination., 2016, 3, 1:16.

35. Zeng, F.; Wei, W.; Li, M.; Huang, R.; Yang, F. and Duan, Y. Heavy metal contamination in rice-producing soils of Hunan province, China and potential health risks. International journal of environmental research and public health., 2015, 12(12), 15584-15593.

36. Islam M.S.; Ahmed M.K.; Al-Mamun M.H. Determination of heavy metals in fish and vegetables in Bangladesh and health implications. Human Ecol Risk Assess, An Int J., 2015, 21(4), 986-1006. 